\title{
Teacher Quality of Life: Perspectives about Their Welfare
}

\author{
Mariana Bairros Hunger ${ }^{1}$, Marília Costa Morosini'2 , Claus Dieter Stobäus ${ }^{3}$ \\ ${ }^{1}$ Graduation in Pedagogy, Pontifical Chatolic University of Rio Grande do Sul, Porto Alegre, Brazil \\ ${ }^{2}$ Postgraduate Programs in Education, Pontifical Chatolic University of Rio Grande do Sul, Porto Alegre, Brazil \\ ${ }^{3}$ Postgraduate Programs in Education and in Biomedical Gerontology, Pontifical Chatolic University of Rio Grande do Sul, Porto Alegre, \\ Brazil \\ Email: stobaus@pucrs.br
}

How to cite this paper: Hunger, M. B., Morosini, M. C., \& Stobäus, C. D. (2016) Teacher Quality of Life: Perspectives about Their Welfare. Creative Education, 7, 23632379.

http://dx.doi.org/10.4236/ce.2016.716228

Received: August 25, 2016

Accepted: October 10, 2016

Published: October 13, 2016

Copyright $\odot 2016$ by authors and Scientific Research Publishing Inc. This work is licensed under the Creative Commons Attribution International License (CC BY 4.0). http://creativecommons.org/licenses/by/4.0/

\begin{abstract}
Quality of life is the conception that the subject has on their situation in life, cultural context and its value system, establishing a relationship with objectives, goals, expectations, standards and concerns. Results from discussions among the authors, from the Hunger Completion of course work, which aimed to (re)learn the conception that teachers have on their own quality of life, also trying to establish the relationship between quality of life, well-being, malaise with the Theory of Baltes (Selection, Optimization and Compensation-SOC Model) in educational spaces and learning through analysis of responses of the SOC Questionnaire from seven public and private teachers, about their quality of life. To analyze the results, it was used as reference discursive textual analysis. The main results were the concern of teachers with the choice and organization of their life goals and the relationship that they made between quality of life with satisfaction, professional and personal.
\end{abstract}

\section{Keywords}

Quality of Life, Teaching Welfare/Malaise, Selection, Compensation

Optimization, Teacher Education

\section{Introduction}

Several nuances permeate the lives and activities of teaching, either in public schools or in private, at all levels of education, from preschool to graduate. As we have several routines and know how life can be fragile before completing our internal development, we must have care and be prepared in terms of life in the physical, psycho-emotional and social spheres. In addition, they are all external events around us, both in family life 
and in society more generally and globally. They can interfere with faces in personal life and working life.

Also, of course, to enter the adulthood, then we realize that no human being is complete. We are always learning throughout our life cycle. We are never ready, which causes some instability to our own being.

As Mosquera (1987: p. 95), "we cannot let consider that he (the teacher) is primarily a human being, with its potential energetic, ideas, mental structuring and limitations".

So it is thinking about who is the teacher, about growing up, developing at every time, that in our life we must make constantly new elections, about our current needs, which faces challenges in the personal and professional areas. The constant new information that we can access, so as the possibility to share it with our peers, makes us review our knowledge, skills and attitudes. All human beings are vulnerable and must change in the daily life.

In the course of teaching, the figure of construction established the teacher figure as a subject to be many things at once: creative, persistent, patient, humorous, competent, friendly, socially active, conscious of its role as an example, ethical and moral, constantly updated, especially on issues connected to teaching and resulting in their own new learning and their students.

Here then it is already one question: does this educator (so complete) actually exist, or is it just an idealization?

We must pay attention to the fact that any teacher before becoming a teacher is a human being, to your wishes and needs, strengths and weaknesses, and it needs to be encouraged and motivated to be this "ideal teacher". Much is still charged this person, with successes and failures along your walks, but we must remember that it is in constant training, noting that is personally and professionally.

Is it for this person (in this case the students we have as teachers) who makes a mistake or error, that we must have tolerance, taking into account how he/she thinks, feels and reacts to external stimuli, such as a human being within the world.

In our context (we would say more broadly Latin American), the educator that is present in today's classroom prioritizes much to their own survival. Being a member of a society in which offers and major disputes are buying and consumption, the message that is constantly absorbed by it is much more that needs to consume to "accomplish in life". In this way, his salary, which should be to solve their basic needs, is much more to survive the constant harassment of a consumer society, and he will need other sources of income and/or other jobs, which gets more and more tired and worn out, physically and emotionally.

Recalling the Basic Needs Hierarchy Maslow (n.d.), Figure 1, it is much more to try to satisfy their physiological needs (the most basic and survival) than the more superiorly placed in Needs Pyramid, as we see the figure.

It would be almost a reversal of this hierarchy, which results in the many feelings of dissatisfaction and even unhappiness of some teachers, who end up interfering directly in their personal and professional development, consequently in educational processes 


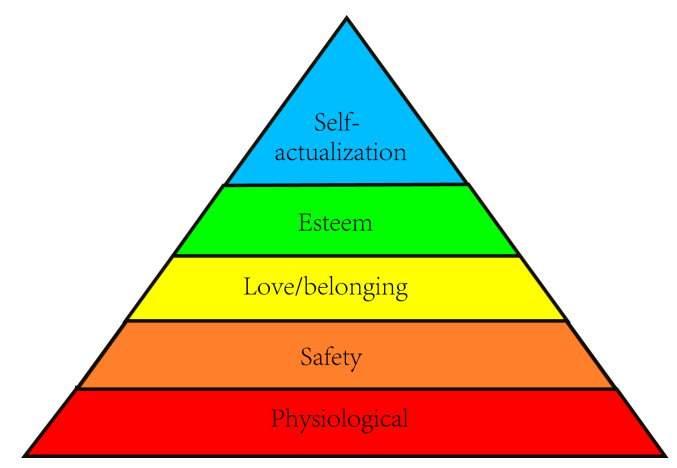

Figure 1. Basic needs hierarchy of Maslow.

and results of their own learning and of their students.

Thus, the basic needs, which are extremely important for the survival of the individual end up being neglected. But when physiological elements are attended, there are spaces in the hierarchy to new achievements to be attended, who assume importance safety or esteem.

All this has a direct impact on quality of life among educators, in your life and within the school environment.

\section{Theoretical Field}

This part is divided in 1, 2, 3: Quality of Life and Quality of Life at Work, Teaching Welfare, and Teaching Malaise.

\subsection{Quality of Life and Quality of Life at Work}

In 1964, the US president voiced the following sentence: "the goals cannot be measured by the balance sheet of banks. They can only be measured by the quality of life they provide to people". The increasing technological development brought a progressive dehumanization to society (Fleck et al., 1999).

The World Health Organization-WHO has a definition of "health as physical, mental and social well-being and not merely the absence of disease" (WHO, 1946). Thus, the health and quality of life go together to fight the morbidity and mortality. However, there is a concept defined on the quality of life, so, WHO continues to work on research and elaborations instruments that can assess the human development index, with quality. The search for an instrument that could assess genuinely the perspective of quality of life led the WHO to organize a multicenter project that had as a result the development of the WHOQOL-100 (World Health Organization Quality of Life) 100 items, developed in 1998 by the WHOQOL Group (WHO, 2002).

Although there is no consensus on the subject Quality of Life (QOL), three aspects were obtained by reflection of some health care experts (WHOQOL Group), of different cultures. They are: 1) subjectivity, 2) multidimensionality and 3) presence of positive and negative dimensions (Fleck et al., 1999; Fleck, 2000). Thus, after the definition of these elements, in 1994, the WHOQOL Group reached the definition of quality of life 
as "the individual's perception of their position in life in the context of culture and value system in which they live and relation to their goals, expectations, standards and concerns".

The QV theme has its origins in the post-war period as a result of the Marshall Plan, aimed at the reconstruction of Europe (Vieira, 1993). Then, QoL gained visibility in other ways such as in workplaces, since the quality of life can influence the behaviors and attitudes of workers, within their areas and labor contexts.

Taveira (2013) developed a research based on social psychology, punctuating the social representations of quality of life in work spaces in the cities of Juiz de Fora and Cataguases (MG). The results showed that the following aspects bring central representation in the quality of life of the participants, they would be: "health", "wellness" and "work-employment." Then, in the first periphery, are: "leisure", "education", "family" and "good financial life/good house." And within their contexts of work, he stood out as core elements: "salary", "working conditions" and "good working environment"; in the background remained "recognition" and "performance-efficiency." Finally, emphasizes that all aspects intertwine through the centrality of "work" as the core of the quality of life.

It is stated that the QWL (Quality of Life at work) has assumed greater importance in the 70s when there was a depletion of cutting labor organizations (Taylorism/Fordism), in which realized an increase in absenteeism, job dissatisfaction and non-adherence of workers to the goals set by managers (Lacaz, 2000). From this reflection, it is necessary to discuss the possible organization of the workplace, the worker participation in discussions on demands, democratic and equitable manner.

\subsection{Teaching Welfare}

Even if the pace of our society does not encourage the evaluation/assessment of the moments of happiness or personal fulfillment, we are encouraged to plan our day-today to overcome the challenges of modern life, for example, maintain employment, financial balance, protect us from urban violence and take actions that promote our physical, emotional and social.

Jesus (2007: p. 24) points out: we need to appreciate the good times in the teaching profession. The good experiences must serve as a reference for building a professional road full of motivation and professional well-being.

The construction of a scientific concept for the well-being has been gaining strength today. According to Ryan, \& Deci (cited by Siqueira \& Padovam, 2008), there are two approaches to welfare; subjective well-being (SWB) and psychological well-being (BEP). The teacher welfare fits within a general concept, subjective well-being, which is related to the "positive psychology" (Marujo, Neto, \& Perloiro, 2000), which describes the BES is developed from reviews cognitive analysis and the experience of positive and negative experiences. In Siqueira \& Padovam (2008) perspective, BES has become one of the main indicators of quality of life.

The concept of BES requires self-evaluation and cannot be evaluated by instruments, 
i.e., only an observation and individual account, the subject itself, could measure wellbeing. Within this context, to maintain its balanced BES is necessary that the subject is aware of their positive and negative experiences, maintaining an index of higher positive emotions than negative emotions. However, this is not to identify a more positive emotion than negative, but rather realize that the different situations experienced were intermingled with feelings of pleasure (Siqueira \& Padovam, 2008). At the same time, there are studies that show that people who live intensely 'positive affects' will also direct much attention to negative emotions moments.

Within the composition of positive affect self-esteem has been identified as a psychological concept that can represent mental health, as in self-assessment, the subject is recognized as having value, with negative and positive aspects. Other concepts have also been pointed out with great relevance, self-image, self-acceptance and self-respect (Siqueira \& Padovam, 2008).

According to Jesus (2007), the concept of teaching well-being can be translated by motivation and achievement of the teacher, because of skill set (resilience) and strategies (coping) that it develops to get to us the demands and professional difficulties, beating them and optimizing their own operation.

Using as a reference the reflection of Jesus can bind with the concept model SOC, this points out the importance of the individual know how to work and adapt their skills, internal and external, in order to accomplish their focus and objectives, such as welfare.

Mendes (2011) did a survey on the health educator in a school of elementary school. With the guiding vision the welfare and educational malaise. The survey had a qualitative and quantitative approach, which results a percentage of $35.4 \%$ of teachers on sick leave, as noted:

Supplemented with a sensitization workshop to highlight the emotional relationships in this school, as for licenses to health care, it was found that $35.4 \%$ of teachers in this school asked this award, showing a high rate. The analysis of the answers we can infer that the group seems to have good self-image and self-esteem, showing satisfaction with his life, though, crave to have more professional success and improve their own health; indicate as partially unmet needs physical and self-realization, respectively, they have demonstrated more satisfied the relationship needs and independence.

The survey also pointed out that these educators have awareness of the factors that cause them discomfort. The research aimed to clarify the importance of self-training, emphasizing spirituality and life stories.

The relevance of teaching well-being in the construction and preservation of the welfare of the student (Jesus \& Abreu, 1994). It can be said that if the teacher does not believe in your work or do not like to transmit his knowledge, the student may feel this relationship does not involve in the process of teaching and learning. Thus, a motivated and self-conducted teacher more likely engages their students to participate more in the classroom environment.

\subsection{Teaching Malaise}

In the early 20th century, it was given three sources for human suffering. They are: the 
superiority of nature, the fragility of our bodies and the rules that seek to model the mutual relationships of human beings in the family, the State and Society Freud according Dohms (2011).

Esteve (1999, cited by Stobäus, Mosquera, \& dos Santos, 2007: p. 263) state that "[...] are the permanent effects of negative character that affect the teacher's personality, as a result of the psychological and social conditions that are exercised in teaching and contributing to it".

The studies on teacher malaise aim to score some negative characteristics in the educator every day. For example, dissatisfaction, the risk of dismissal, the possible lack of responsibility, the desire to leave education, exhaustion, anxiety, stress, neurosis and depression. Esteve (1992) considers stress one of the main predictors of teacher malaise. Many believe these are factors that have its roots in the characteristics of today's society. After many studies it was concluded that the teaching profession compared to other professions has "a higher level of stress" (Kyriacou, 1987: p. 147).

The field of research on teacher malaise has grown in recent years and, according Mosquera, Stobäus, \& Dornelles, (2008) the teacher malaise is a social disease that ends up being transformed into personal, which is caused by the lack of support society to teachers, both in their goals to be achieved, as the current compensation and professional recognition.

For Jesus (2007: p. 12), the main factors causing the teacher malaise are:

- A fast pace of life in which you need to respond quickly to the demands and requests of society;

- Extremely competitive environments, where the main living values are lost, such as solidarity and cooperation;

- The professional instability, to the teachers of the private network. Where demand is greater than supply, leading to many the need to hide behind a mask of efficiency, fearing the loss of their employment,

- The instability and uncertainties plans depend on uncertain factors and often the achievement of objectives is connected with uncontrollable factors.

Mosquera, Stobäus, \& Dornelles (2008) complement the reasoning of Jesus (2007), saying that the main causes of the malaise teachers are: the great demand for labor and the absence of a timely manner; paperwork, sucking teaching time, as it should be exercising the practice of teaching and disbelief in education, as a modification factor on the basic knowledge of students. They also highlight some factors with deeper roots and can be found in deficiency:

- The State and the lack of government plans to unleash a truly effective education;

- Need for citizenship education where values human rights and attitudes of tolerance;

- Lack of a philosophy of education for all and all worked, discussed and negotiated;

- Disabilities to consider knowledge as a real value that provides tools for the changes in a world where there is poverty, ignorance and ignorance.

There are still some major causative aspects of minority and more direct areas that 
may result in a malaise situation. Esteve (cited by Mosquera, Stobäus, \& Dornelles, 2008) separates the causative factors as follows: first order and second order. Are the second-order factors, which have broad impact on the behavior of teachers and their realities?

1) Changes in the role of the teacher and traditional socialization agents.

2) The teaching role: defense and contradictions.

3) Modification of the support of the social context.

4) The objectives of the education system and the progress of knowledge.

5) The teacher's image.

The primary factors, "unfolding" of the previous ones, have a direct effect and extreme and that need to be analyzed. Being them:

1) Material resources and working conditions.

2) Violence in schools.

3) Teaching depletion and accumulation of demands on the teacher.

The factors mentioned above, which draws the most attention is the teacher burnout. This is a clear consequence of the teaching excessive stress, which can marry discouragement and hopelessness, resulting in the abandonment of their duties and responsibilities (Jesus, 2007). Finally, I believe that the outcome of this process would be the failure in teaching and learning relationship.

The situation of teacher malaise is alarming. However, a look caregiver and evaluator have been exercised. The field of study and research has been expanding by building a close eye on the subject.

\subsection{SOC Model}

Thinking about human development, it is to reflect on the stages of life of us all. There are features for these do, some growth (gain) and other decline (loss) of course they are interconnected, because all the elements that build life need a balance, because the subject of adaptive skills (Bajor \& Baltes, 1987).

The model selection, optimization and compensation model SOC, developed by Baltes, Baltes, Freund, \& Lang (1999), discusses how individuals, of any age, use and reuse internal and external resources such as strategies to maximize your gains and minimize their losses, throughout the evolution of their lives.

When the optimization aspect, which is the strategy that the subject uses to acquire or improve some of your skills or resources, to a certain goal, for example, the initial reflection on the strategies that can be addressed to the achievement of a goal in specific (see in Table 1).

As for compensation, skill that a person needs to use to keep functioning, physical or mental, declining situation (loss), for example, the search for new resources when it is no longer possible to perform a task as usual (see in Table 2).

In terms of selection, which is divided into two, elective selection (SE) and loss-based selection (SBP). The first, SE, plans to prioritize goals, adapting the standards and situations, for example, the commitment to a particular goal, keeping sole focus to achieve 
Table 1. Example question of SOCQ, subsection optimization.

$\begin{array}{ccc}\text { O } 10 & \text { I think about exactly how I perform my best } & \text { I do not think much about how to carry out my } \\ \text { plans. } & \text { plans, I just try. }\end{array}$

Table 2. Example question of SOCQ, subsection Compensation.

$\begin{array}{cc}\text { When I cannot do something as well as it } & \text { When I cannot do something as well as it used to, so } \\ \text { C } 8 \text { used to, I look for other ways and means to } & \text { I accept it. } \\ \text { achieve. } & \end{array}$

success. The second, SBP, the choice of goal happens at the expense of another. For example, realizing the failure of certain activities, which elect will receive exclusive attention, with a view to improvement. Both approaches can be applied in personal and professional life, seeking balance and satisfaction, physical and emotional (see in Table $3)$.

Starting from the SOC model, Margret and Paul Baltes, in partnership with Baltes, Baltes, Freund, \& Lang (1999), developed the SOC Questionnaire, a questionnaire that seeks to operationalize the adaptive processes of the individual, through 48 questions, 12 items for each approach.

Almeida (2013) Thesis verified the process of translation and cultural adaptation of SOCQ. His study showed three parts over three articles, only one published. Throughout the first part of the research, adapted and translated instrument was adequate to Brazilian culture and content validity. However, the first phase was not enough to use it, necessitating the continuation of the analysis process.

Almeida, Resende, \& Stobäus (2013) stressed the need for continuity of psychometric tests, using the original structure of QSOC with the translation and adaptation to Brazilian culture.

The article described the cross-cultural adaptation of the Selection, and Compensation Optimization Questionnaire (SOC) for the Portuguese language and the application to subjects in late adulthood phase. The instrument aims to assess the degree of adaptation of the elderly face the daily challenges and thus explain its successful aging. The process of cultural adaptation involved the following phases: initial translation; translation synthesis; back-translation (back translation) to English; review by a committee of experts to evaluate the semantic equivalence, idiomatic, experimental and conceptual and pre-test the final version, with the participation of 34 elderly. From this process it was possible to propose the draft instrument in Portuguese.

The following cross-cultural adaptation followed with rigorous process of analysis of psychometric indices, ensuring the reliability and validity of the results. This hike resulted in two articles, unpublished, since the perfecting of an instrument depends on successive analyzes and discussions (Almeida, Resende, \& Stobäus, 2013).

Questioning the subject on aspects such as selection of targets and time optimization is a way to raise awareness of the effects that these aspects can cause in our life contexts. Thus, based on the vision of Jesus (2007), in which he emphasizes the importance of 
Table 3. Example SOCQ issues, subsections elective selection and selection based losses.

\begin{tabular}{ccc}
\hline SE 2 & $\begin{array}{c}\text { I always focus on the most important goal at } \\
\text { any given time. }\end{array}$ & I'm always working on several goals at once. \\
SBP 5 & $\begin{array}{c}\text { When I cannot keep doing something as it } \\
\text { used to, I direct my attention to my most } \\
\text { important goal. }\end{array}$ & $\begin{array}{c}\text { When I cannot keep doing something as it used to, I } \\
\text { direct my attention, as always, to all my goals. }\end{array}$ \\
\hline
\end{tabular}

preparing themselves and form to achieve the well-being, will focus on the model of the subdivisions to form evaluators/reflective questions.

\subsection{Relation of Quality of Life, Welfare/Malaise and the SOC Model in Spaces of Education and Learning}

In 1956, Selye (cited by Jesus, 2007: p. 28), presented the definition of the word stress as "set of non-specific biological reactions to any requirement adjustment, reflecting the preparation of the subject to respond to new demands". In other words, stress is not only a force which depletes us, making us open our eyes to what is negative around us, but rather, an organic movement that can nourish us to answer new questions and difficulties.

Jesus also gives us a second definition, pointed out by Lazarus \& Folkman (cited by Jesus, 2007), stress as the result of the exchange of information between environmental variables and personal variables when evaluating our demands is higher than the evaluation the individual makes their own resources, which are personal, interpersonal and organizational.

Both definitions, although distinct, show us that stress is a "pressure" on the subject requiring a response to the situation or adaptation to circumstances.

The Baltes, Baltes Freund, \& Lang (1999) SOC Model, as complements Néri (2006), presents the prospect that anyone can handle and adapt its resources, internal and external, to achieve their life goals with balance and stability. They also claim that this process is part of human development, allowing maximization of gains. However, the main aspect of this approach is the possibility of the subject to reduce physical and mental wear God, putting into practice the strategies of selection, optimization and compensation as a result building a lasting well-being, to improve quality of life.

As Jesus (1996: p. 134) said, "[...] the emphasis in terms of intervention should be of primary order, since the teachers already affected by the malaise not always ask for help, tending symptoms to fester each again".

Developing a process as exemplified above, where resources are exploited and handled for improvement, is really in direction of a healthier education. For often stress levels are not absorbed constructively, generating the so-called malaise (Jesus, 2007). This situation occurs when the strategies and resilience skills are proved to be inadequate/insufficient. Why, several times, professional teachers, reduce their efforts and dedication to their activities, seeking to return to their initial emotional state. This process leads to a decline or break in the process of teaching and learning, causing not 
only the lack of teacher recognition with their profession, but also disinterest/ abandonment of the student to the classroom environment.

\section{Methodological Procedures}

This study, based on the Pedagogy Course Conclusion Study of Hunger (2014) has a qualitative approach, seeking to explore the opinion of a group of educators on their quality of life. We use the definition of Flick (2009), that part of the concept of social construction of reality under study, being interested in the perspectives of the participants in their day to day practices and in their everyday knowledge on the issue under study.

The initial goal was to explore the design of educators on their quality of life through the application of reflective questionnaire on quality of life, prepared for this work, from the Selection Questionnaire content optimization and compensation (SOC) of Baltes, Baltes, Freund, \& Lang (1999), 10 teachers, containing the following five essay questions.

- As the organization of your life goals? For example, how many and what goals directs more attention at any given time (Elective Selection).

- How do you deal with success and failure in carrying out its proposals for life? For example, when performing versus "fail" in a goal, what is your attitude towards the situation (Based Selection Losses).

- When you choose a goal to accomplish in your life, as your preparation to reach it? (Optimization).

- Realizing the decline/decrease/loss of some of their skills, natural or not, as you read in this situation? (Compensation).

- What is your conception of quality of life? Describe how this theme works in your life.

\subsection{Analysis of Results}

Through the questionnaire analysis of quality of life, built with essay questions for the survey, you can see relevant information. After the research, the questions/answers were analyzed separately and then made the crossings of the answers, in order to maintain fidelity to the general objective of the research, with the Discursive Textual Analysis, proposed by Moraes \& Galiazzi (2006).

As explained in the methodology of the work, it is important to resume the distributed instrument was built with the pure aim of provoking the teacher's reflection on their quality of life. Through it, register the forms of organization and selection of life goals, frustrations and the quality of working life.

\subsection{Profile of Participants}

The group of participants in this study is aged between twenty two twenty six years with the highest number of participants at the age of twenty-three. Among them only 
two have a workload of twenty hours per week, the other five work an average of forty hours per week.

In this group of four participants live with their parents and three share expenses and living with girlfriend/ boyfriend (only two teachers with children). Regarding the education level of the participants, all with higher education, and three have expertise and two of them have Masters Degree students. Regarding the age of the students, three work only with Early Childhood Education, one with only basic education (A.I) and three others divide their day in Early Childhood Education (students between 2 and 6 years) and Elementary Education (A.I.) (students between 6-6 and 11-12).

\subsection{Results and Discussion}

\subsubsection{Attitude and Planning Action to Achieve Goals}

When performing reading the responses reported in the questionnaire replies, we can see that there is a concern on the part of participants, with the initial organizational goals, devoting greater focus on the general selection process goals, as the preview explanation about the SOC model above, on Optimization, Compensation, Elective Selection and Selection Based Losses.

It became clear in the responses that almost all participants take time/attention to the choice of goal. However, among the seven participants: three described having a look attend to their priorities when planning and choosing their life goals, establishing relationships with present events in their lives, such as optimization objective: "race goals and will eliminate every obstacle to reach my goals" (1); "My goals and/or life goals are organized taking into consideration the existing targets today in my life" (3).

Two other teachers draw annual targets: "Trace annual goals and always try to balance the essential non-necessary" (2); "I organize my goals every year, [...]. Put near the objectives and easier to perform and also record the long-term goals" (4).

One participant stated pursue real goals, describing a very concrete level of organization: "I often set goals that have real possibilities to be achieved".

Only one teacher said not propose organizational goals, making clear his thoughts: " $I$ am super planned nor methodical. I have dreams and I guide me quite by 'intuition', energy, prayers, etc. I try to draw paths/ steps" (6).

In writing this participant, not realizing a planning action, you may notice a lack of concern with organizations, getting clear its "stripped" (as "easygoing way") to act in life. However, this stance contrasts one of the main ideas of Jesus (2007: p. 26) in which it specifies "the teacher well-being as a set of skills, including the ability to create strategies and plans". Further clarifying in a troubled context, such as the teaching profession, it is necessary the ability to organize itself to meet the demands and difficulties, proposing to overcome and optimization of our own operation.

The model selection, optimization and compensation Baltes, Baltes Freund, \& Lang (1999) has as its vision the ability of the individual features, to handle your skills, achieve your goals and objectives. Thus, it focuses clear the relevance of an organizational stance, planning time and vital resources to be dedicated to specific purposes. 


\subsubsection{Organization and Time Media Optimization}

When reading the reports, on issues regarding the optimization and organization of time, you can see the various ways that humans use to organize your time. This, which in his absence can "suck" our energies, prevents us from acting in moments of decision.

In this issue, five participants reported using a specific organizational methodology, such as: "Trace and step-by-step and I will forward all very calculated" (1); "I organize with calendar (month view) that record the deadlines to achieve my goals Those that can be won in the long run and do not have dates will usually be postponed and sometimes take too long to happen" (2).

A highlight its ambivalence, emphasizing not have as much persistence to achieve and accomplish goals: "When I order a goal I take it very seriously, I am firm and try to think positive only, but if this process I fail, however minimal, I have no motivation, I $m$ not persistent, step to think I will not be able, and sometimes give up" (4).

One participant reports a form of abstract organization where planning is internal: " $I$ try soon see at the beginning the way to go, and so plan the steps you need to take to achieve it' (5).

One participant also reports that there is no organization of its time, saying: "I dare try, I try, I dedicate myself" (6).

We live in a stressful society, with great motivational crisis (Jesus, 2007). Many of the factors that contribute to the constant stress crises are related to the lifestyle of a social group. Would they be: fast pace of life, professional and personal fickleness, competitive environments and the lack of control or uncertainty regarding certain life outcomes. Looks like these can paralyze us when unexpectedly arrive. Thus, plan and organize life goals gives us a sense of security, allowing clear and rational thinking in times of crisis.

\subsubsection{Behaviour/Reactions by Frustration of Situation}

It was asked to participants in this study his way of dealing with the failure of its objectives/goals.

Among the seven participants, five reported initial reaction of sadness that is transformed into reflexive stance, aiming the improvement to continue on new goals. "Well, I have no difficulty in accepting the frustrations and the life of ups and downs" (1); "There is always the possibility of failure, I try to remember that may not work, but do not let me 'hang' because of this possibility. I think the more sure everything better result if the contrary, patience" (2!); "Obviously when failure in something I created a lot of expectation, I feel super frustrated and upset", (4) "I seek to give more and more my best to achieve them. In the event of "failure" I sometimes feel sad initially. I intent be increasingly reflective and think where I can improve, [...]”. (6).

Another participant reports not only find it difficult to face and accept the frustrations and last teacher says: "I unfold to do everything and not 'fail. This ends up creating sometimes a big physical wear (sleep little, I become more stressed, tired ...)" (3). Irreducible posture can lead to emotional and organic ills. 
One says: "I do not think that has 'failed' in any order, but upon some difficulties rethink about what is needed to be achieved, even if it takes more than originally planned" (7).

Frustrations and failures are inherent factors of the path of life. Knowing how to deal with our feelings and act upon these conflicts is that will allow us to keep mind and body healthy. In this view, we can talk of the factors that can cause paralysis and withdrawal, lack of motivation to act before acting in the face of difficulties.

\subsubsection{Reaction before Loss of Moments Natural Skills Declines}

Many of the malaise of the cause are external and can deal with them through planning and organizations. However, there are of human development factors that often cannot avoid and so little change. To face the loss of occasions or decline of our abilities we need self-training, you need to educate yourself.

Situations of loss of resources, such as vision or hearing. They are natural abilities and, with human development, may suffer a decline or loss. Regarding losses and decreases in their abilities, three teachers described trying to redeem this loss. "Of course, I dedicate myself more and try to regain this ability is very important Otherwise dedicate myself to something else" (1); "I believe the first reaction is to try to justify myself, for myself, the causes of this decline, initially looking for ways to not consider it really a loss, but a consequence of certain circumstances" (5); "I try to rescue, foster, but I miss more initiative, motivation" (6).

One said to seek help (with medical or psychological treatment): "I try to help (experts, therapy, exercises" (2).

One said he did not see or feel these losses/declines: "I do not see a decrease or loss of my abilities, but lack of time to exercise them" (3).

A theme like this, at a young age as the participants (between 22 and 26 years), can be abstract. For these subjects are distant from one phase of life in which the decline appears. According Almeida, Resende, \& Stobäus (2013: p. 54), “compensation strategy refers to the use of a resource for maintaining a given level of desired operation, when the individual suffers some loss". Following this reasoning, the teachers who know better experience and handle these situations, they managed to achieve their goals and objectives with greater ease in a more healthy development, moving towards the quality of life.

\subsubsection{Design Faculty on Quality of Life}

The conception of the subject about his place in life, in their cultural context and value system, together with their expectations, standards and concerns. This is the definition of quality of life, according to the WHOQOL Group (WHO, 2002).

When we asked our participating teachers as their design on the theme "Quality of life" these were their responses: five of them establish relationship between personal and professional satisfaction with QOL.

Another important point of this questioning was the importance of QOL in the historical context of these teachers. An important observation to make is that, when di- 
rected to completing the questionnaire were asked to reflect on his professional life.

One teacher said: "Quality of life involves being in good physical, mental, psychological and emotional conditions today do not consider myself as a person with quality of life" (3), highlighting a very solid reflection on the time of life that passes...

Similarly, but now positively, another said: "Quality of life, in my opinion, is a healthy relationship between organic, psychological and emotional aspects. The balance between professional, human relationships with the environment, family, and so on... I need to help me more and to feel pretty resilient' (7), commenting that this has recoverability.

Three participants mentioned something toward being managed to reach a successful conclusion in relation to their quality of life: "To be held from well with life, to be in family, have health ... Quality of life requires a willingness to engage in. things that give me pleasure, that complete me and that somehow provide happiness" (1); "Having quality of life is to do what makes you well, be happy with what you achieved, seek to accomplish what you want to be able to enjoy the family, take time just for you, to have a profession that loves wonder" (2) "Well true that recently I think of quality of life. I now realize that I need more time to devote to me and the family, so I started to plan small changes that provide these improvements" (4); "My conception of quality of life is the feeling of satisfaction and fulfillment before all aspects of life: work, leisure, fami$l y$, personal relationships, whether with friends or partners Quality of life is pleasure to perform daily activities" (6).

As Mosquera (1987) said, we fail to consider the teacher as a being with idea, positions and constraints. Another important point of this questioning was the importance of QOL in the historical context of these teachers.

An important observation to make is that, when directed to completing the questionnaire were asked to reflect on his professional life.

\section{Conclusion}

The objective of this research was to explore the design of seven early-stage teachers on their quality of life, establishing relationships with prospects of teacher welfare and SOC theory. With the participating teachers at the beginning of teaching, working in public schools and private schools. It could be observed that most participants have a positive outlook on their quality of life and well-being, despite the bad weather of the day-to-day. It was revealed that much of this group of participants established direct relationship between self-conduct and quality of life.

With the application of argumentative Quality of Life Questionnaire, we approached points that were not necessarily related to QOL, as the choice of goals/objectives and declining skills. However, we believe that these approaches have direct power in our behavior towards the factors responsible (in part) by the teacher malaise, as well as allow us to a reflective attitude for the well-being and positive mental and physical health.

By questioning the teachers on how they want to choose their life goals and organize their time and functions to conquer them, most of them responded that they organized 
in order to establish achievable goals and good chances of success. Thus, one of the main aspects that cause discomfort and malaise, instabilities and uncertainties of life in societies, becomes less threatening.

Participants reported the most part, no problems in dealing with the failures and frustrations of life, clarified the initial reaction of sadness and scored a feature of too much importance and the ability to reflect on the cause of failure. This reflective stance, of course, generated learning, forming these subjects for future adverse situations that could cause emotional and physical immobility, and preventing this teacher to follow with his whole being and motivated. At the same time, the inability to think about the "failure" and the fickle search for perfection can result in too much wear and generating frustrations and failures in other aspects of life, personal and professional.

When asked to the teachers to reflect on their decline and loss of skills was aware of the possible confusion. Asking young women to talk about the loss of a feature is difficult, a thought too abstract, with possible exceptions, which did not occur in this study. The participants made clear not go through this, keeping a discourse of "get lost" or "seek", with future features. This reaction can be expected from a group of women in early adulthood, possibly the answers are different in a group of teachers in retirement process. I want to emphasize that, yes, the age of the participants is not in a negative way, but determining this issue.

Was unanimous among the participants that the term "Quality of Life" involves more than just physical health or joy in work/family? Clearly, the extention of the issue and how comprehensive speaking about the results of QOL, are not just by a good salary, a stable relationship, own or rented house, it takes more. Need also be held in the workspace, or by satisfaction and peace in the family environment, the physical health, accessibility, financial peace of mind, resilience and security. The path to well-being and quality of life is a constant process of education, health education.

From this vision, we need to look closely at the teaching profession, not a fateful vision, which states that this carries one of the largest rates of stress, but with a proud posture, describing the teacher as a professional/subject with great social interactivity, dynamic and growth opportunities and training and valuing small great moments of triumph.

\section{References}

Almeida, S. T. de (2013). Tradução, adaptação cultural e validação da versão em português do brasil do selection, optimization and compensation questionnaire (SOCQ) para uso entre idosos sedentários e atletas máster [Translation, Cultural Adaptation and Validation of the Portuguese Version of Brazil's Selection, Optimization and Compensation Questionnaire (SOCQ) for Use among Sedentary Elderly and Master Athletes]. Tese (doutorado em Gerontologia Biomédica), Porto Alegre, RS: Instituto de Geriatria e Gerontologia da PUCRS.

Almeida, S. T. de, Resende, T. De L., \& Stobäus, C. D. (2013). Adaptação transcultural do Selection, Optimizatiom and Compensation Questionnaire (SOC), para aplicação a idosos [Cross-Cultural Adaptation of the Selection, Optimization and Compensation Questionnaire (SOC) for Application to the Elderly]. Revista Brasileira de Geriatria e Gerontologia, 16, 18099823. http://dx.doi.org/10.1590/S1809-98232013000200003 
Bajor, J., \& Baltes, B. (1987). Theoretical Propositions of Life-Span Developmental Psychology: On the Dynamics between Growth and Decline. Developmental Psychology, 23, 611-626.

http://library.mpib-berlin.mpg.de/ft/pb/PB Theoretical 1987.pdf

Baltes, P. B., Baltes, M. M., Freund, A. M., \& Lang, F. (1999). The Measurement of Selection, Optimization and Compensations by Self-Report. Berlin: Max-Planck-Institute.

http://dlc.mpdl.mpg.de/dlc/view/escidoc:33564/recto-verso

Dohms, K. P (2011). Níveis de mal/bem-estar docente, de autoimagem e autoestima e de autor realização de docentes em uma escola tradicional de Porto Alegre [Levels of Teacher's Malaise/ Wellbeing, Self-Image and Self-Esteem and Self-Atualization in a Traditional School in Porto Alegre]. Dissertação (Mestrado em Educação), Porto Alegre, RS: Faculdade de Educação da PUCRS. http://repositorio.pucrs.br/dspace/handle/10923/2872

Esteve, J. M. (1992). O mal-estar docente [The Teacher Malaise]. Lisboa: Escher.

Fleck, M. P. de A. (2000) O instrumento de avaliação de qualidade de vida da Organização Mundial da Saúde (WHOQOL-100): Características e perspectivas [The World Health Organization Instrument to Evaluate Quality of Life (WHOQOL-100): Characteristics and Perspectives V]. Ciência \& Saúde Coletiva, 5, 33-38.

Fleck, M. P. De A. et al. (1999). Desenvolvimento da Versão em português do instrumento de avaliação da qualidade de vida da OMS (WHOQOL-100) [Development of the Portuguese Version of the OMS Evaluation Instrument of Quality of Life]. Revista Brasileira de Psiquiatria, 21, 19-28. http://dx.doi.org/10.1590/S1516-44461999000100006

Flick, U. (2009). Desenho da pesquisa qualitativa. [Qualitativeresearch design] Porto Alegre: Artmed, 2009.

Hunger, M. B. (2014). Qualidade de vida docente: Perspectivas do educador sobre seu bem-estar [Quality of Teaching Life: The Educator's Perspective on Their Welfare]. Trabalho de Conclusão de Curso (Pedagogia), Porto Alegre: Faculdade de Educação da PUCRS.

Jesus, S. N. de (1996). Uma abordagem sociopolítica do mal-estar docente [A Sociopolitical Approach to Teacher Malaise]. Revista Portuguesa de Pedagogia, XXX(1), 56-64.

Jesus, S. N. de (2007). Professor sem stress: Realização profissional e bem-estar docente [Teacher Stress: Professional Achievement and Teacher Welfare]. Porto Alegre: Mediação.

Jesus, S. N. de, \& Abreu, M. V. (1994). Study of Teachers' Motivation to Motivate Students by the Theory of Planned Behavior. Paper presented at the23rd International Congress of Applied Psychology, Madrid, 17-22 July 1994, 13 p.

http://files.eric.ed.gov/fulltext/ED400235.pdf

Kyriacou, C. (1987). Teacher Stress and Burnout: An International Review. Educational Research, 29, 146-152.

Lacaz, F. A. de C. (2000). Qualidade de vida no trabalho e doença/saúde [Quality Working Life and Health/Illness]. Ciência \& Saúde Coletiva, 5, 151-161.

http://dx.doi.org/10.1590/S1413-81232000000100013

Marujo, H., Neto, L., \& Perloiro, M. (2000). Educar para o optimismo [Educating for Optimism]. Lisboa: Editorial Presença.

Maslow, A. H. (n.d). Introdução à Psicologia do Ser [Toward a Psychology of Being] (2nd ed.). Rio de Janeiro: Eldorado.

Mendes, A. R. (2011). Saúde docente: uma realidade detectada-Em direção ao bem-estar e a realização profissional [Teachershealth: A Detected Reality-Toward the Wellbeing and Job Satisfaction]. Dissertação (de Mestrado em Educação), Porto Alegre, RS: Faculdade de Educação da PUCRS. http://repositorio.pucrs.br/dspace/handle/10923/2721

Moraes, R., \& Galiazzi, M. do C. (2006). Análise textual discursiva: Processo reconstrutivo de 
múltiplas faces [Discursive Textual Analysis: A Multiple Face Recontructive Process]. Ciência \& Educação (Bauru), 12, 117-128.

http://www.scielo.br/scielo.php?script=sci arttext\&pid=S1516-73132006000100009

Mosquera, J. J. M. (1987). Vida adulta [Adulthood] (3rd ed.). Porto Alegre: Sulina.

Mosquera, J. J. M., Stobäus, C. D., \& Dornelles, J. (2008). O mal-estar na docência: Causas e consequências [The Malaise in the Teaching: Causes and Consequences]. Revista da ADPPUCRS, No. 2, 23-34.

http://www.portalanpedsul.com.br/admin/uploads/1999/Formacao De Professores/Trabalho/ $06 \quad 2008$ O MAL-ESTAR NA DOCENCIA CAUSAS E CONSEQUENCIAS.pdf

Néri, A. L. (2006). O legado de Paul B. Baltes à Psicologia do Desenvolvimento e do envelhecimento [Legacytothe Psychology of Development and Aging]. Temas em Psicologia, 14, 17-34. http://pepsic.bvsalud.org/scielo.php?script=sci arttext\&pid=S1413-389X2006000100005

Siqueira, M. M. M., \& Padovam, V. A. R. (2008). Bases teóricas de bem-estar subjetivo, bem-estar psicológico e bem-estar no trabalho [Theoretical Basis of Subjective Well-Being, Psychological Well-Being and Well-Being at Work]. Psicologia: Teoria e Pesquisa, 24, 201-209. http://dx.doi.org/10.1590/S0102-37722008000200010

Stobäus, C. D., Mosquera, J. J. M., \& dos Santos, Bettina S. (2007). Grupo de pesquisa mal-estar e bem-estar na docência [Research Group Malaise and Wellbeing in Teaching]. EducaçãoPUCRS/RS, XXX, 259-272.

http://revistaseletronicas.pucrs.br/ojs/index.php/faced/article/viewFile/3562/2787

Taveira, I. M. R. (2013). Representações Sociais da Qualidade de Vida no Trabalho [Social Representations of Quality of Life at Work]. Curitiba: Editora CRV.

Vieira, D. F. V. B. (1993). Qualidade de Vida no Trabalho dos Enfermeiros em Hospital de Ensino [Quality of Life at work of Nurses in a Educational Hospital]. Dissertação (Mestrado em Educação), Porto Alegre: Programa de Pós-Graduação em Administração da UFRGS. https://www.lume.ufrgs.br/bitstream/handle/10183/18719/000114897.pdf? sequence=1

World Health Organization (WHO) (1946). Constitution of the World Health Organization. Basic Documents, Geneva: World Health Organization.

World Health Organization (WHO) (2002). WHOQOL Instrument: Scoring and Coding for the WHOQOL Instruments. Geneva: World Health Organization.

\section{Submit or recommend next manuscript to SCIRP and we will provide best service for you:}

Accepting pre-submission inquiries through Email, Facebook, LinkedIn, Twitter, etc.

A wide selection of journals (inclusive of 9 subjects, more than 200 journals)

Providing 24-hour high-quality service

User-friendly online submission system

Fair and swift peer-review system

Efficient typesetting and proofreading procedure

Display of the result of downloads and visits, as well as the number of cited articles

Maximum dissemination of your research work

Submit your manuscript at: http://papersubmission.scirp.org/

Or contact ce@scirp.org 